Др Душан М. Иванић

\title{
СРПСКА ПРИПОВИЈЕТКА ДОСИТЕЈЕВОГ ДОБА
}

Рад је осврт на основне аспекте српске приповијетке Доситејевог доба (период од 80-их година XVIII вијека до 40-их година XIX вијека). Издваја се типолошко-генетски аспект утицаја превода Д. Обрадовића, његовог дјела у цјелини и идеја просвјетитељства на обликовање првог типа приповијетке у српској књижевности (у календарима, алманасима и часописима). Приповијетка слиједи европске обрасце (сиже, фабула), национализује се тематиком, отвара се према говорном језику и фолклорној традицији (Вук Караџић). Криза просвјетитељско-рационалистичких начела наговјештава романтизам (доминација страсти, патос љубави и страдања, родољубље, патос).

Кључне ријечи: Доситејево доба, приповијетка, европски обрасци, национализација, језик.

1. Појам Доситејево доБА се налази већ код савременика нашег просвјетитеља (Соларић, нпр.), али су му временске границе у српској књижевној историографији остале неодређене. Тим појмом Драгиша Живковић обухвата XVIII и XIX вијек, до 1814. године, кад настаје Вуково доБА, у које укључује романтизам и реализам. ${ }^{1}$ Ако би се хтјела ова два доба разграничити, онда је 1814. година, као што се зна, само почетак велике деценије Вуковог рада (народне пјесме, Срйски рјечник, граматика, приповијетке). Међутим, Вуково дјело не потискује Доситејев утицај (тј. доситејевски тип књижевности), доминантан у свим врстама прозне ријечи, готово до средине XIX вијека, у дјелима писаца старије генерације и до краја тога вијека

${ }^{1}$ Периодизација Д. Живковића (Живковић 1994/ 1: 36), постављена врло широко („Период 1700-1800 [1850] - (Доситејево доба)“, „Период 1814-1890-[1914] (Вуково доба)“), претпоставља велика преклапања праваца и стилова, укључујући широке распоне и једног и другог доба. Уже гледано, оправдано је Доситејево доба рачунати од 80-их XVIII вијека до 40-их XIX вијека (уп. ИвАнић 2019). Овом аспекту периодизације књижевности одговарају и тезе А. Милановића о периодизацији српског књижевног језика (МилАновић 2019). 
(Јован Суботић, Јаков Игњатовић, Љубомир П. Ненадовић, Милица Стојадиновић Српкиња, Стефан М. Љубиша и др.). Вук радикално утиче на брзо ширење народног језика у доситејевском типу дјела.

Насловом овог рада хоће да се повеже и генетички и типолошки аспект теме. С једне стране је несумњив утицај Доситеја Обрадовића на ауторе приповијетки (и кратких прозних облика), с друге је тип приповијетке какву је уносио својим преводима или подстицао својим дјелом. Широко узев, могЛо би се рећи да се ради о ПРОСВЈЕТИТЕљСКОМ ТИПУ (МОДЕЛУ) СРПСКЕ ПРИПОвИЈЕТКЕ, обликоване у неколика основна параметра:

- једни су језички: писана је славеносрпским језиком, односно мјешавином црквенословенског и српског (народног) језика, у његовим регионалним варијантама;

- други су морфолощко-рейорички: у језгру модела налазе се једноставни дидактички облици (примјер, пословица, басна, поука или „наравоученије“, како би рекао Доситеј) или реторички поступци и жанрови (нпр. алегорија, парабола); модел се, међутим, ослања и на сложеније врсте и технике, нпр., приповиједање у писмима, у аутобиографском излагању, у путописима;

- трећи су функиионални: редовно тежи поучном дјеловању, и то у сфери моралних одлика појединца, касније обухватајући породични живот, еротске везе, положај жене и мушкарца у браку;

- четврти су $\bar{и} е м а \bar{и} с к о-м о \overline{и в в с к и: ~ п р е д м е т ~ п р и п о в и ј е д а њ а ~ с е ~ т и ч е ~ и з-~}$ бора/рјешења одређеног животног проблема/ситуације (пријатељство, љубав, вјерност, доброчинство, лаж, подвала и сл.) или испољавања типизираног карактера.

Сви елементи модела пролазе еволутивне мијене: језик се све више приближава говорном (народном), једноставни облици опстају као самостални или се уклапају у сложеније наративне цјелине. Већ тридесетих и четрдесетих година XIX вијека у овај модел улазе творевине фолклорног поријекла. Проширује се прича (фабула), али се и даље уоквирује дидактичко-поучним смислом и функцијом (Атанасије Николић (1831), Јован Суботић (1846) и др.). ${ }^{2}$ Нешто касније приповијетке почињу да се заснивају на романтичарским чиниоцима: дидактично и здраворазумско уступа афектима и страстима (љубав и мржња, освета, подлост, хероичност) и новим вриједностима (љубав/народност). У приповијеци Љубица (1839) Теодора Павловића љубавна страст на први поглед суочава се са осјећањем гријеха, мржње, крви/злочина и близине смрти (Српкиња удата за Грка, у Цариграду, заљуби се у босанског муслимана, па кад сазна да је муслиман, хоће да га убије).

Не улазећи у логичко-филозофску и естетичку страну просвјетитељства, како се оне очитују у европској традицији, издвајамо однос између просвје-

${ }^{2}$ В. нпр. следеће текстове поменутих аутора: А. Николић: Вјерни йобрайим или Оїлеgало буяућеїа вијека, ЛМС, 7: 1831; Ј. Суботић: Стефан Јакшић: по народној песми, ЛМС, 73 (1846): 74-115; Суђеница (новела по народној скаски), Драгољуб, 1846. 
титељских идеја и новелистичких дјела у српској књижевности, која наративизују (српски речено: поприповјеђују) вриједности здравог разума (моћи суђења, процјењивања, одбацивање злоупотреба религиозних догми, сујевјерја, човјекољубље, вјерска толеранција и сл.), ослањајући се уз то на јеванђељске поруке, моралне или правне норме. Једне су приповијетке ишле ка (псеудо)историјској тематици, најчешће везане за српски средњи вијек (династичке борбе, сукоби обласних господара), за доба пропасти српске државе и за борбе против Турака (до Карађорђевог устанка). Историјски (најчешће псеудоисторијски) јунаци и догађаји постављају се у однос према водећим парадигмама просвјетитељске традиције и њених моралних норми. Друге су везане за искуство, опажање, посматрање и издвајање онога што је опште, у опозицијама приписаним актерима и радњама (стар/млад, поштен/непоштен, искрен/подао, свој/туђи, мушкарац/жена, корист/штета, паметан/глуп, добар/зао, насилник (локални моћник или разбојник)/жртва (дјевојка, туђа супруга). Предочава се као животно искуство скуп ситуација или стања (карактер) са одређеним морално-религиозним ставом (потврђујући награду врлини, а казну пороку). (Страдање носилаца добра доћи ће са јачањем предромантичарских тенденција, што је знак кризе повјерења у просвјетитељску апологију здравог разума, врлине и доброчинства.)

2. Приповијетка у српску књижевност улази с преводима Доситеја Обрадовића, ако се изузме рукописна заоставштина Гаврила Стефановића Венцловића, гдје је сачувана Повести о йріовиу и низ „повести“ и једноставних облика (ПАвић 1972). Међутим, ни њен развој ни њено устаљивање нису били могући без периодике. Први, елементарни облици приповједачких текстова повезани су с кратковјеким календарима Георгија Михаљевића (Будим, $1807,1808,1813)$, потом са бечким Новинама сербским (1813-1822) Димитрија Давидовића и Димитрија Фрушића. У њима се под насловом (или наднасловом) „приповетка“ објављују кратки, једноставни текстови из инојезичке штампе, о знаменитим људима и занимљивим догађајима у вези с њима, сведени на духовит или неочекиван обрт. Убрзо се за такве текстове употребљава наднаслов "анегдота“. Ови прилози су писани готово чистим народним српским језиком, можда већ уз сарадњу Вука Караџића (блиског издавачима Новина, Димитрију Давидовићу и Димитрију Фрушићу). Један од тих прилога (1814, бр. 210) непосредан је претеча (или извор) Вукове шаљиве приповијетке Еро и каяија (Нарояне срииске йрийовијетике, 1821).

Анегдота или шаљива причица је језгро увођења фолклорне стилизације и живог говора у писани текст. Ови ће се облици наћи и као основа за развијену приповијетку. Ниједно од тога двога није случајно. Већ је Доситеј у том кратком и лако преносивом облику повезивао усмено и животно искуство с одређеним поукама, намјерама, тенденцијама. Елементарне облике, мотиве и технике приповиједања усменог поријекла Доситеј је укључио у писане текстове, наговјештавајући пут којим ће српска проза ићи у XIX вијеку. У њега је граница између анегдоте, шаљиве приче и басне порозна, 
особито тамо гдје су у баснама носиоци радње људи (ковач, старац, рибари, хвалисавац), а садржина се редовно у „наравоученијима“ искоришћава за поуку.

Тим ће путем ићи и самосталнији, изворнији приповједачки текстови: фабула је основа за поуку, коментар, закључак (тичу се морала, поштења, правде, родољубља, љубави и др. вриједности). Прве српске приповијетке су често настајале као прилагођени преводи (посрбе) текстова из других књижевности/језика, илустрације одређене идеје или повод за њу. Могло би се закључити да је идеЈА и генезом и садржином самосталнији дио приповједачког текста: она производи причу, прича се смишља да представи, оживи, предочи идеју. Али саме те односе не треба, како се често чини, сматрати противним природи приповједачке прозе и њене функције. Напетост између поуке/идеје и приче (радње, фабуле) траје откако се мисли о књижевности и откако су књижевни облици почели да се издвајају из окриља нерашчлањеног усменог ткања. Олга Фрејденберг је структуру нарације у старој грчкој књижевности описала као „двочлано приповедање које се састоји од једног сликовног и другог појмовног члана“, а да се сликовни члан йрет̄вара у наpauију и повезује с реалним процесима, штавише - да једнократност и појединачност у нарацији служе као средство појма (стр. 270, 272).

У раној фази свог развоја српска приповијетка садржи у елементарном облику напетост између „сликовног и појмовног“. Независно од изворности појединих текстова, у њима се радња (фабула) редовно преводи на идејни план, а тиче се животних, моралних, вјерских, националних (родољубивих) оквира. Утилитарност и идејност (у широком смислу ријечи), прокажене у каснијим тумачењима, незаобилазне су функције приповиједања чак и кад се то изричито не тражи или не очекује, без обзира на то што је естетски пожељно да се идеја не надмеће с причом и да причу не замјењује. Може се рећи да није идеја узрок што су приповједни слојеви (радња, јунаци) у нашим раним текстовима остали неразвијени или схематични: настајање прича великим дијелом је подстакнуто функционализацијом и фикционализацијом идеје, без које би једва било писане приче, осим можда у анегдотским облицима.

У Доситејевом дјелу је приповијетка заступљена преводима и посрбама или прерадама, и то у врстама које одговарају у основи приповијеци у водећим европским књижевностима друге половине 18. вијека. ${ }^{3}$ Најчешће

\footnotetext{
3 Попис приповиједака (и сл. облика) у Доситејевом дјелу (наводимо само главни наслов књиге), без потпунијих библиографских података, који се могу наћи у издањима Доситејевих сабраних дјела, 1961, књ. 1-3, у редакцији Ђ. Гавеле, Ј. Шаулић и Б. Маринковића, односно издања 2007-2008, књ. 1-6, у редакцији М. Д. Стефановић, М. Матицког и Д. Иванића. Поред оквирне класификације мјестимично остављамо коментаре о могућем сврставању.

Тип источњачке приче

1. Абдала и Балсора, једна персијска историја (Собраније, гл. 7).* Љубавна прича налик Ромеу и Јулији.

2. Виденије Алмета дервиша (Собраније, гл. 8). *Визија, филозофска.
} 
су међУ њима иноскАЗАЈЕмЕ ПОВЈЕСти (алегоричне и параболичне приче моралне или филозофске садржине), које су више него „повијести“ филозофско-етички огледи у облику извјесне радње. По том су источњАчкЕ, односно ИСТочнЕ ПРИПовИЈЕТКЕ (како је стајало у поднасловима), назив за приповијетке блискоисточне и далекоисточне тематике (арапске, кинеске, индијске, персијске). У Доситејевом Собранију (1793) прва је АлЕгоРичнА причА Гора вјежестива и истиине: Јеgно алеїорическо или иносказајемо вияјеније. Иако се овај текст понекад узима као источњачка приповијетка (П. Поповић, М. Д. Стефановић), ни по чему се то не може потврдити, те је на другом мјесту то и за Павла Поповића „прича <..> философска“, „,казује како је тешко доћи до истине и колико је препрека на путу“ (Поповић, 2000: 92). Могло би се рећи да је и морално-поучна, јер читаоца у алегорији упозорава на заблуде у путу до истине и врлине. Овом низу преведених прича/повијести/ „видјенија“ и „сновидјенија“ може се прикључити новелистички обликована ПричА из животА, ${ }^{4}$ унутар наравоученија уз басну Jасйреб и кукавица.

3. Један пар папуча (Собраније, гл. 9). * Шаљива новела.

4. Пут у Вавилон, једна алегорическа повјест (Собраније, гл. 15). *Философска прича, с поуком.

АЛЕГОРИЧнЕ ПРИЧЕ

5. Гора вјежества и истине: Једно алегорическо или иносказајемо видјеније (Собраније, гл. 2);

Неке иносказајеме йовјесӣи (Собраније, гл. 19)

6. Кривица и стидљивост;

7. Срећа и несрећа;

8. Благочестије и сујевјерије: У једном видјенију;

9. Видјеније Мирсино; *П. Поповић (СД, 5: 90) напомиње да су оне у основи моралне, филозофске, често у облику алегорије.

Басне (1789; 1961, књ. 1; 2007, књ. 2)

10. Истина и прелест;

11. Пут у један дан;

12. < Једна лепа арапска историјица > (Басне, уз „Путници и топола“). *Заправо је парабола о разноликости свијета („није истина да је бог све за самога човека створио“).

13. <Један кратак разговор> (Басне, „Јастреб и кукавица“); *Дио наравоученија, заокружена прича из живота.

Мезимач $(1818 ; 1961$, књ. 2; 2008, књ. 4)

14. О мудрости и промислу у управленију (гл. 3):

15. Цу-И илити филозоф, из књиге чувствителнога човека (гл. 4)

16. Сновидјеније мудрога о обајателној сили мечтанија (гл. 5)

МоРАЛНЕ ПРИЧЕ

17. Лаузис и Лидија, морална повјест из господина Мармонтела (Собраније, гл. 23);

18. Аделаида, пастирка алпијска, повјест морална из Г. Мармонтела (Собраније, гл. 24)

${ }^{4}$ Појам се односи на приповједне текстове који се заснивају на стварним догађајима и личностима. Та врста приповиједања ће се наћи у опусима С. Милутиновића Сарајлије, J. С. Поповића, Ј. Ј. Змаја, Л. Костића, С. Матавуља и др. 
Разговор између капетана Рашковића и калуђера Светогорца, у далматинском Голубићу, уоквирен је улазном и излазном ситуацијом и одвија се у оштрој, отвореној полемици, са духовитом поентом, на готово чистом народном језику (чистим као Вуков језик у приповијеткама), претходећи и Вуку и каснијим писцима фолклорне оријентације (С. М. Љубиша).

3. Први изворни приповједачки (новелистички ${ }^{5}$ ) покушаји потичу од Еустахије Арсић (1776-1843). Њена Повесӣ о Савки и Кайи (Каленgар за лет̄о 1807. Георгија Михаљевића) састоји се из разговора двију жена, с два супротстављена става, један, да жена треба да се образује (да чита Доситеја), други, да жени не требају књиге („Бога ти, ти си женско“). ${ }^{6}$ Дијалошка форма омогућује да се суоче полемичке или дидактичке позиције ликова кроз питања и одговоре. Овај примјер наговјештава да је једна од могућих линија стварања приповијетке било стапање са есејистичким замислима, посебно са етичким ставовима. Заправо се ради о наративизованим идејама, не и о облику који би се подударао са општим обиљежјима приповијетке као врсте. Дијалошко дидактичко приповиједање било је веома раширено у књижевности тога доба. Код нас је тај облик подстакао Поучииеелни майазин за gеиу (Будим, 1787, књ. 1, 1793, књ. 2, 1800, књ.3, 4), популарно дјело Жан Мари Лепренс де Бомон у преводу Аврама Мразовића, састављено из разговора између учитељице и њених ученица. ${ }^{7}$ У тим разговорима се причају басне/бајке или „историје“, те се коментаришу у духу различитих (дјечјих) карактера. Све су то слободне приче, варијације везане за библијску или за античку традицију, у широком распону од препричавања канонских текстова до апокрифних адаптација библијских, митолошких и историјских мотива. Тај тип директне поучне приче, са односом учитељ (учитељица) : слушалац (слушатељка), а потом са њеним алтернацијама (отац - дијете, свештеник - вјерник, младић - дјевојка), опстаће све до средине 19. вијека (свакако и касније, посебно у дидактичкој прози). Наративни текстови Еустахије Арсић су непосредан одјек или наставак овог обрасца. У њима је позиција говорник - слушалац аналогна позицији аутор - читалац.

Еустахија Арсић ће потом објавити кратку параболичну причицу $C \overline{\bar{u}} a-$ раи и йри млаgића (ЛМС, 1829), која је заправо дио рубрике Морална йоу-

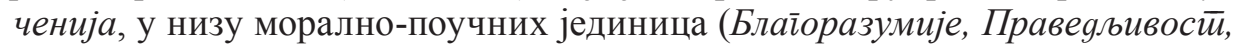

\footnotetext{
5 Појам новелистички се узима алтернативно, пошто се основни појам (ПРиПовЈЕдАчки) може схватити шире, има шири опсег значења (може се узети у све облике приповиједања, приповијетку, роман, епску пјесму, анегдоту итд.).

${ }^{6}$ В. МилАнков 2001: 134; према Теодори Петровић, из чланка о Доситеју, у Ковчежићу Вуковоі и Досийејевог музеја (1963), наводи дијелове из овог календара и поткрепљује тврдњу да се ради о тексту Е. Арсић, објављеном анонимно.

${ }^{7} \mathrm{O}$ популарности те збирке свједоче и рукописни преводи на јужнословенском тлу, уп. Д. Иванић, Љепотица и звијер на Балкану/међу Србима//Домети (Сомбор), 37: 140-141 (пролеће - лето 2010), стр. 50-57.
} 


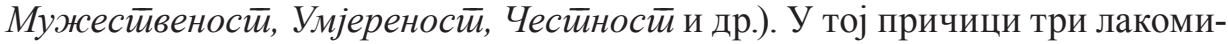
слена младића се подругују старцу који сади воћке. Сва тројица убрзо погину, а старац са унуком и сином долази под дрво које је засадио и говори о правим врлинама честитости: благоразумије (опасност од „полутанца “, који је протрчао кроз школе, а остао без правог васпитања), праведљивост, мужество, умјереност, па благопристојност и честност („И с овим сврши старац бесједу своју“, стр. 118).

Уз Еустахију Арсић треба поменути и Константина ПеичићА. Његова приповијетка Пиљии (ЛМС, 1826) траје као разговор о смислу постојања између младог и старог пиљка. Приповједачка срж заплета је апстрактна: почетни побуњенички став малог (младог) пиљка се кроз разнолике примјере преображава у мирење с поретком, те је он, лежећи у прашини, на крају разговора ипак срећнији од оних бића која су на висини (храст) и слама их вихор. Идеја о прихватању друштвеног поретка истовремено је идеја о извјесном здраворазумском устројству свијета. Писана у традицији сократовског дијалога (из одговора и питања, живих слика и примјера, порука и поука) и оновремене европске басне, Пеичићева проза у тим једноставним облицима садржи и причу и процес самоспознаје (преласка из незнања у знање, у ново разумијевање свијета): наивно поимање другог и сопствене судбине мали (и млади) пиљак замјењује поимањем заснованим на искуству и разумској процјени. (Морфолошки синкретизам тадашње српске прозе допушта да се овај дијалог сматра приповијетком. Текст, с друге стране, свједочи да се језик књижевне прозе упадљиво приближава језику савремене говорне ријечи.)

Типолошки односи првих оригиналних српских приповиједака према Доситејевом дјелу су још очитији него генетски. Преводећи угледне и популарне европске писце свога времена (Мармонтела, Адисона, Гоција, в., П. Поповић), Доситеј је уносио у српску приповједачку прозу релативно модерне обрасце. Облик и смисао излагања (виђење, алегорија, филозофска, морална, поучна прича), тематика/мотиви (правда, памет, љубав), све је подстицало слободан рад маште око избора фабуле и јунака. Подређена том често пренесеном (алегоричном) морално-филозофско-поучном смислу, ова проза је имала типске јунаке, ситуације и мотиве. ИсточњАчкА ПРичА постаје доста честа у алманасима, од Давидовићевог Забавника $(1815,1816,1820)$. Одржавала се махом у облику посрба или прерада (нпр. у алманасима Уранија, 1837-38, Авала, 1846/47). Особеност тога типа приче је отвореност за алегоричан смисао, али и за алузије и инсинуације својствене сатири. Кад бирају изворе, преводиоци проналазе текстове који се односе на актуелне домаће прилике. Чини се да је тако радио Јован Стејић преводећи приповијетку Уgовища у Цери (Уранија, 1838), гдје је “најважније место у причи $<\ldots>$ оштра критика тираније и грамзивости владара“" (калиф, кадија, удовица) (Деретић, 1980: 146). Истој идеји одговара и Стејићев превод драме Госйоgар и роб (Уранија, 1838), што само појачава утисак о политичкој актуализацији и функционализацији прозног штива, а нарочито његов превод 
Лукијановог Тиранина (СтЕЈић, 1839), с коментарима који се несумњиво тичу актуелних прилика за владавине кнеза Милоша. Средином 19. вијека источњачку причу наставља да пише и млађа генерација домаћих писаца. Међу њима је Јаков Игњатовић (Араӣ и Персијан, 1844), који и касније има склоности ка сличним мотивима (Манзор и Џемила, 1860, приповијетка о љубави између Српкиње и Арапина, обоје из поробљених народа у турском царству), те Лаза Костић (Махараца, 1860), али више не с морално-филозофским фабулама или алегоријама, већ са страстима/осјећањима јунака у меЂусобној вези. ${ }^{8}$

С Доситејевим преводима је и ишао и модернији тип тзв. моРАЛнЕ, односно моРАЛно-ПоучнЕ приповијетке (Лаузис и Лияија, морална повјест и Ageлаиgа, йасииирка алйијска, обе Мармонтелове, у Собранију, 1793). Осим тога Доситеј је понекад уз басне саопштавао сличне „историјице“, варијације на мотиве и поуке у њима. Из басне Пуйници и йойола таква „историјица“ се преноси у првој свесци Сербске лет̄ойиси (Лейойис Майице срӣске) као посебна приповједна јединица, што би могло бити знак нове осјетљивости на жанровске изазове или на нове могућности разврставања. Српски алманаси, већ од Давидовићевог Забавника, пуни су превода морално-поучних приповиједака, повремено уз оригиналне (?) примјере такве прозе, у којим прогоњена врлина побјеђује порок, невиност се одупре изазовима, љубав

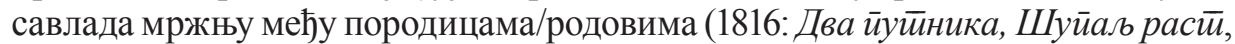
обе приповијетке имају јунаке са српским именима, али су свакако посрбе; 1818: Бојана Обраяова, Ружица, 1819: Милан и Милева, љубавници бирају смрт да потврде вјерност). И касније, у Забавнику (1820) има покушаја да се пишу приповијетке с домаћом тематиком: Себислав (неауторизована приповијетка) за јунака има Томислава, краља "српског и далматинског " и његовог сина, који га спасава од грчких уцјена. Остало су преводи, а као жанровска група издвојају се алегорије (Три луйке, Анйеноров сан, Басне шпанског аутора Сале, Муж и жена и др.). У првим годиштима Забавника наводе се аутори, махом с њемачког језичког подручја. Касније изостају и такви подаци. Тешко је рећи колико је Давидовићев избор дјеловао на српске приповједаче. Једна од приповиједака из Забавника, Нешито за мужески йол (1821), наћи ће се у Банайском алманаху Д. Тирола (1827), назнака отварања приповијетке према грађанском, породичном животу.

4. У овим примјерима, највише због њихове једноставности, добро се оцртавају будућа тежишта српске приповијетке. Једна су оријентисана на искушења морала, правде, поштења; друга на спознају/искуство, саопштена у параболично-алегоричним конструкцијама (басна као модел); трећа, на

\footnotetext{
${ }^{8}$ Касније се томе току, на новим основама, прикључују Бранислав Нушић (Рамазанске вечери) и Драгутин Илић. Дискретан одјек ових тема су и приче о племенитом Турчину (Ибищ-аїа Стевана Сремца), у несумњивом додиру с причама о племенитом дивљаку (и иновјерцу).
} 
искушења страсти, части, поштења и љубави. Животна свакодневица и догађаји које изазива подређују се поукама, а онда основним афектима, стањима љубави, мржње, љубоморе, непријатељства, жалости, што је већ знак преласка у (пРЕд)РОмАнтизАм. Релативно рано се појављују знакови разуђивања српске приповијетке у опозитне типове, нпр. Љубииа Теодора Павловића (ЛМС: 1839/49) и Рђав йосао, зао конаи Василија Суботића (ЛМС: 1841/54). Разлика је између њих у тенденцији: друга приповијетка већ у наслову има истакнуту поуку-поруку (која се потврђује кроз ланчану причу о лажној љубави, превари/заблуди, прељуби, освети), а прва је лишена таквог дидактичког оквира и развија се као отворена прича о љубавној страсти суоченој са вјерско-националним препрекама (или предрасудама). Страсти као стања јунака/јунакиња све су чешће теме, прожете повезаним мотивима љубави, мржње, изневјеравања, искључивости (вјерске, националне, социјалне). У Павловићевој приповијеци писмо пријатељу најављује необичне доживљаје, слиједи долазак и приповиједање о чудној љубави Српкиње (у Цариграду, удата за старог Грка) према босанском муслиману (Мирза), све док није сазнала да по вјери није Србин: иако га воли, покушава да га убије, јер је прекршила свој завјет. Ту је и страсна љубав на први поглед, осјећање гријеха, мржње, крви и близине смрти. (Колико су ови мотиви блиски Јакшићевим приповијеткама, нпр. Неверна Тијана, они се додирују и са приповједачким хиперболама и антитезама Лазе Костића.)

Између Доситејевих превода и раних покушаја оригиналне српске приповијетке, првих деценија 19. вијека, у периодици су објављивани преводи и посрбе, изабрани по мјери која одговара моралној, дидактичној или источњачкој приповијеци, често у њиховом преплету. Томе претходи доминација једноставних врста писаног или фолклорног поријекла, каква је садржина Каленяара Георгија Михаљевића (Будим, 1807, 1808, 1813). Осим дидактичке прозе Е. Арсић (1807), у њему је (год. 1813) доминантна анегдота (МАтицки 1986: 175. - Забавник (Беч, 1815-1816; Будим, 1818; Беч, 1819-1821; Београд/ Крагујевац, 1833-1836), у уводнику обећава благонаравне, поучне и забавне повијести или приповијетке. (Ова двојна жанровска ознака, $\bar{u} о в и ј е с \bar{u}$ или $\bar{u}$ рийовијейка, може значити и једно и друго или њихову истоврсност; уз то иде и њихова двојна природа, да су йоучне и забавне.) Афирмацијом врлине, моралности, оптимизма, све су те прозне творевине, независно од тематске разноликости (моралне, љубавне, источњачке и др.) у основи моралне ирийовијейке (ДЕРЕтић 1980: 17). Забавник је по врстама продужење Доситејевог корпуса превода, са изричитом оријентацијом на приповијетку као врсту. У првој години излажења објављене су (анонимно) приповијетке с персијском и арапском тематиком, а услиједиће преводи тада познатих и популарних италијанских, њемачких и других аутора (Франческо Соаве, Конрад Готфрид Пфефел, Саломон Геснер, Сигисмунд Хердер и др.). У преводе тих текстова често се уносе српска имена и локалитети те се заправо обликују као посрбе. Други круг садржаја Забавника су басне, анегдоте, примјери, параболе, алегорије и сновиђења, поетска проза, такође махом без 
података о ауторству, свакако на грађи тадашњих њемачких и других алманаха или зборника (у рубрици „Смјесице“). Неки од тих мотива из једноставних врста наћи ће се касније као сегменти или водећи чиниоци шаљивих календара, комедија, романа: ликови тврдица, лаже и паралаже, кратки облици, пародије (дјела Ј. С. Поповића ${ }^{9}$ ) или ће се преобликовати као афоризам, примјер, шала, досјетка.

Међу утицајним врстама нашле су се идиле тада славног Саломона Геснера (интензивно превођене у периодици, објављене су и као засебно издање $)^{10}$, најчешће обликоване дијалозима јунака, што ће се одразити и на ране примјере српске приповијетке. Владислав Стојадиновић Чикош објављује такву идилу (Заяовољстиво човека щччастильивим чини. Тихомиљ и Љубивој, ЛМС, 1827). Наслов је морална изрека о људској срећи, која се преноси на јунаке као илустрација, примјер, потврда; приповијетка почиње цитатом јунакове мисли о срећи и заgовољстиву, као најадекватнијој ријечи; атмосфера - прољетно вече, зелена трава и храст изнад њега; наилази познаник, одан ноћним задовољствима: даље је конфронтација двају гледишта о срећи Љубивој је види у дружењу, весељу, нераду, а Тихомиљ - у раду, спокојству, умјерености. У Сербском нарояном листиу је више оваквих прича (нпр., Драіољуб и Љубииа, 1837, бр. 44: Драгољуб држи бесједу о пролазности љепоте;

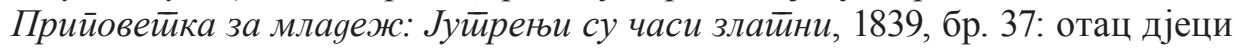
прича поучне историје). Тај ће образац дјеловати дуго у српској приповијеци са сличним етичким мотивима, све до С. М. Љубише и реалиста, код којих ће се развијати карактери, осамостаљивати радња и јачати слика средине, уз широке захвате из фолклорне подлоге.

Оригинална српска приповијетка ће се споро отимати од превода/посрба. То убједљиво илуструје Давидовићев Забавник у другом течају (18331836), гдје је објављено 50-ак приповиједака, а ниједна од њих није оригинална (ДЕРетић 1980: 107). Ни београдски алманах Уранија $(1837,1838)$, који заузима упражњено мјесто Давидовићевог Забавника, а доноси прилоге свих знатнијих српских књижевника (Ј. С. Поповић, С. Милутиновић Сарајлија, М. Светић, Ј. Стејић, Д. Исаиловић и др.), готово да и нема оригиналних новелистичких прилога. Такав би могао бити текст Димитрија Тирола, Престичйленије из синовне љуббови. Почиње бајковитом формулом неодређености (,Један убоги земљеделац беше у великој нужди“), а завршава се домољубивом и поданичком поруком: љубав према оцу изједначава се са љубављу према домовини и цару! Фабула је анегдотска, једноепизодична, с необичним заокретом или преокретом, наглашава морални аспект дјеловања ликова: циљ повезан с врлином оправдава прекршај. Вриједност текста, међутим, није у поуци (у оном што „оправдава “), већ у неочекиваном исходу (преокрету) и оном што је језгро радње. Поучност, сведена на

9 J. С. Поповић је најбољи примјер. Упоредити, М. Флашар (2017: 135-434), Д. Иванић.

${ }^{10}$ Соломона Геснера Идиле / [превео] П.М<атић>, Беч, 1827. 
општи став (идеју), уступа пред приповједношћу (фабула, заплет, актери), која постаје носилац промјена и новина у развоју жанра.

Још један тип обликовања приче има коријен у Доситејевим дјелима. То је прича-портрет или портрет-прича, гдје се низом појединости из реалног живота предочава динамичан карактер/лик. У Совјешиима здраваїо разума се нека општа карактерна својства конкретизују у понашању човјека који их посједује (тврдица/среброљубац, властољубац, славољубац) (уп. ДеРЕтић 1974: 89). Прве обимније примјере овај тип приче има у прози Јована Стејића, у сликама одаџије (писац ода), срећног човјека, тврдице, старовоље, младожење, адвоката, назадњака, љекара (Зайиска 'yсойщих' Николе Клайи$\hbar a, 1839)$. Иако без наративне динамике, ови портрети/слике концентришу негативне карактерно-социјалне особине око једног типа улоге и понашања (нарочито Блаж Травоцеђа, 1839, 140-143), гдје су нерадници, надрикњиге, лажни књижевници, пијанице... За ове портрете је Константин Богдановић употребио атрибут „рапсодичан“, у приказу једне од Стејићевих књига, оног дијела који се састоји од хумористичко-сатиричних портрета савремених карактера или случајева. ${ }^{11}$ Овим појмом Богдановић је указивао на њихову композиционо-тематску разуђеност. Они имају наративно језгро у ликовима и цртицама које у облику ситуација или дијалога и описа допуњују или предочавају карактерна обиљежја. Ауторова сатирична намјера око ових портрета разбија се често у забавно, хумористичко штиво. Тај модел каталога, инвентара, серије, сведен на ређање карактерних особина изабраних група (младожење, ђаци, нације) постаће један од средишњих поступака у приповиједању Јакова Игњатовића (Трияесей іолина из живойа Милана Нараниића), док ће се као фрагментарно средство обликовања појављивати готово код свих писаца (набрајање, ређање у фазама, контрастима, истовјетностима) или ће добити посебан облик у шаљиво-сатиричним козеријама (милобрукама) Јована С. Поповића.

5. Приповијетка Доситејевог доба је бирана и стварана (преведена и оригинална, ако се уопште ради о оригиналности) у видокругу просвјетитељских идеја и класицистичког или сентименталистичког устројства (стил, фабула). Национална тематика у дијелу приповиједака је неутралисана њиховом анонимношћу, сижеом, радњом и њиховом конфигурацијом (најчешће су то заправо преводи са елементима посрба). У то вријеме је Вук у Срйском рјечнику (1818), уз ријечи давао и њихово тумачење, често као мале приповијетке (шаљиве приче, приче из живота - случајеви, кратке бајковите приче), а потом ће објавити и своју прву књижицу, преузету из Новина србских, Наровне срйске йрийовијетике (1821). Та збирка садржински и морфолошки добрим дијелом одговара жанровској оријентацији штампаних издања тих деценија, претежно састављена из шаљивих кратких прича, какве су биле

${ }^{11}$ Преглед књиге под надписом Нови йрилог за Дущеввну забаву от Јована Стеића у Новом Саду 1839. Печатане, ЛМС, 13: 4 (1839), 120-128. 
и прве преведене збирке почетком 19. вијека. ${ }^{12} \mathrm{C}$ обзиром на природу фолклорне традиције, и ове су приче интернационалне, али су у оквирима језика (стила), радње и јунака биле израз српске патријархалне средине.

У Доситејево доба је српска приповијетка је добила европски оквир (жанрови, облици излагања, водеће идеје), потом да се постепено национализовала (тематски), овладава говорним језиком и дуго остајала у мјешавини са књишким језиком (лексика, синтакса) и стилом. Испрва узима теме из средњег вијека (карактеристично је да бира династичке сукобе између властеле и тиранију локалних господара), а потом се отвара се према грађанском животу. С Вуковом збирком (1821) добила је још један стилско-реторички и мотивско-тематски правац, жив у српској прози до данас, као што је остао жив и онај доситејевски, у наративизацији грађанског живота и не мање отвореног или прикривеног сукоба врлине и порока, искушења љубави, родољубља, вјере, слободе и присиле.

\section{ЦИТИРАНА ЛИТЕРАТУРА}

Деретић, Ј. Алманаси Вукової доба. Београд, 1980.

Живковић, Д. Евройски оквири срйске књижевносӣи. І. Београд, 1994.

ИвАнић, Д. Доситејево доба у периодизацији српске књижевности. Периоgизаиија нове срииске књижевностии: йоводом 150. іодищњище рођења Павла Пойовића. Београд: САНУ. Одељење језика и књижевности. Књ. 31. 2019, 125-136.

ФлАшАР, М. Изабрана gела Мирона Флащара. ІІІ йом, прир. В. Јелић, Н. Ристовић, Бг - Н. Сад, 2017.

Матицки, М. Календари Георгија Михаљевића. Сӣуgије и йрађа за истиорију срйске къижевностии 2. М. Фрајнд (ур.). Београд, 1986.

МилАнков, В. Еустиахија йл. Арсић и њено доба. Н. Сад,2001.

МилАновић, А. Корелације између периодизација књижевног језика и периодизација књижевности. Периодизаиија нове сриеске књижевностии: иоовоgом 150. Гоgищњице рођења Павла Пойовића. Београд: САНУ, Одељење језика и књижевности. Књ. 31. 2019, 136-149.

ПАвић, М. Гаврил Сеиефановић Вениловић. Београд, 1972.

Поповић, Павле. Нова књижевност. І. П. Палавестра (прир.). Сабрана gела Павла Пойовића V. Београд, 2000.

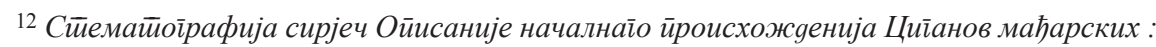
с њекими иррииовјеgками / списано Петром благородним от Аси-Маркович. - В Будиње градје, 1803. - Разби-бриїа или Ком различни йрийовјеgки за нейовољне мисли расӣерайи, време

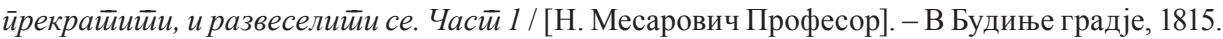
(*Пренесено савременом ћирилицом.) 
Dušan M. Ivanić

\section{SERBIAN SHORT STORY OF DOSITEJ'S AGE}

\section{Summary}

The paper describes the genesis of the Serbian short story of Dositej's age (approximately the period from the 1780's until 1840's). Dositej's translations give the Serbian short story a European framework (genres, narrative forms, leading ideas) and it is then gradually nationalized (thematically) and it starts introducing vernacular mixed with literary style (lexis, syntax). The concept of characters and story fit with Enlightenment ideas and forms (idyll, dialogic story-telling, portrait-story, didactic and moral story, etc.). It partly takes topics from the medieval times and then it opens up towards the contemporary civil life and folklore tradition in the intertwinement of Enlightenment and (pre)romantic foci.

Универзитет у Београду

Филолошки факултет

Катедра за српску књижевност са јужнословенским књижевностима

dusan.div@gmail.com 